\title{
The role of mast cells in vascularized recurrent pterygium
}

\section{O papel dos mastócitos no pterígio recidivado vascularizado}

\author{
Ali Riza Cenk Celebi ${ }^{1}$, Caner Ozbey², Galip Ertugrul Mirza ${ }^{3}$
}

\begin{abstract}
Objective: To determine and compare the mast cell count in primary and recurrent vascularized pterygium, and in normal bulbar conjunctiva.

Methods: The study included 22 patients with primary pterygium (PP group) and 28 patients with vascularized recurrent pterygium (VRP group) that underwent excision via the limbal conjunctival autograft technique. Normal conjunctiva samples were collected from the superotemporal bulbar conjunctival region, just temporal to the site from which the autograft conjunctival tissue was harvested. The total number of mast cells in the pterygium (primary and recurrent) and control tissue samples was calculated microscopically using $1 \%$ toluidine blue stain under $400 \times$ magnification.
\end{abstract}

Results: The mean mast cell count in primary and vascularized recurrent pterygium tissue was $7.45 \pm 2.06 \mathrm{~mm}^{-2}$ and $16.11 \pm 4.33 \mathrm{~mm}^{-2}$, respectively, and the difference was significant (independent samples t-test, $\mathrm{P}<0.001$ ). The mean mast cell count in pterygium tissue was significantly higher than that in normal conjunctiva tissue in both groups (Student's t-test, $\mathrm{P}<0.001$ ).

Conclusion: An increase in the number of mast cells might play a role in the pathogenesis of recurrent pterygium. Determination of a mast cell count cut-off value could be of diagnostic significance for recurrent pterygium.

Keywords: Mast cells; Pterygium/diagnostic; Recurrence; Toluidine chloride; Conjunctiva

\begin{abstract}
RESUMO
Objetivo: Determinar e comparar o número de mastócitos em pterígio primário e recidivado vascularizado, assim como em conjuntiva bulbar normal.

Métodos: $O$ estudo incluiu 22 pacientes com pterígio primário (grupo PP) e 28 pacientes com pterígio recidivado vascularizado (grupo VRP), submetidos à exérese por meio da técnica de transplante de conjuntiva autólogo de limbo. Amostras de conjuntivas normais foram coletadas da regiäo bulbar superotemporal, próximas do local a partir do qual o tecido autólogo de conjuntiva foi colhido. O número total de mastócitos em amostras de tecido dos pterígios (primários e recidivados) assim como dos controles foi calculado microscopicamente utilizando azul de toluidina a $1 \%$ sob magnificação de 400x.
\end{abstract}

Resultados: O número de mastócitos médio no tecido pterígio primário e recidivado vascularizado foi de $7,45 \pm 2,06 \mathrm{~mm}^{-2}$ e $16,11 \pm 4,33 \mathrm{~mm}^{-2}$, respectivamente, e a diferença foi significativa (amostras independentes $t$-test, $P<0,001$ ). A contagem média de mastócitos no tecido pterígio foi significativamente mais elevada do que no tecido conjuntivo normal em ambos os grupos (teste $t$ de Student, $P<0,001$ ).

Conclusão: Um aumento no número de mastócitos pode desempenhar um papel na patogênese do pterígio recidivado. A determinação de um valor de corten a contagem de mastócitos pode ser importante para o diagnóstico de pterígio recidivado.

Descritores: Mastócitos; Pterígio/diagnóstico; Recidiva; Cloreto de tolônio; Conjuntiva

\section{INTRODUCTION}

Pterygium is one of the most common surface ocular lesions. It is a fibrovascular neoformation characterized by a triangular or wing-shaped overgrowth of abnormal conjunctiva onto the cornea, degenerative and hyperplastic changes, proliferative and inflammatory features, and a rich vasculature ${ }^{(1)}$. Inflammation induces angiogenic pathways, resulting in neovascularization, which contributes to the development and growth of pterygium. Mast cells are involved in chronic inflammation ${ }^{(2)}$. Mast cells have also been implicated in both normal and pathological angiogenesis, seen in chronic inflammatory diseases and tumors. The number of mast cells is highly correlated with the extent of both normal and pathological angiogenesis ${ }^{(3)}$. Mast cells release a number of angiogenic factors, of which vascular endothelial growth factor (VEGF) is considered among the most active ${ }^{(4)}$. The number of mast cells in a pterygium is higher than that in normal conjunctiva ${ }^{(5,6)}$. Ribatti et al. reported that mast cells are involved in the angiogenesis of pterygium, and may play a role in its pathogene$\mathrm{sis}^{(7)}$. Another highly active angiogenic factor released by mast cells is tryptase, a serine protease stored in mast cells. There is an increase in the number of mast cells containing FGF-2 and other angiogenic factors in their secretory granules in pterygium ${ }^{(5,8)}$.
The pathogenesis of pterygium is not yet fully known, nor are the differences between primary pterygium and recurrent pterygium. A few studies that differentiated primary and recurrent pterygia reported that the levels of VEGF, basic fibroblast growth factor, and substance $P$ were significantly higher in recurrent disease ${ }^{(9)}$. Markers for vascular endothelial cells such as CD31+ are increased in pterygium, which supports angiogenesis ${ }^{(10)}$. A higher number of CD34 cells - a mast cell marker - in recurrent versus primary pterygium has also been reported ${ }^{(11)}$. The present study aimed to determine and compare the mast cell counts in primary and recurrent vascularized pterygia and in normal bulbar conjunctiva.

\section{METHODS}

\section{Patients and study design}

This prospective case-control study included 22 patients with primary pterygium (PP group) and 28 patients with vascularized recurrent pterygium (VRP group). All patients underwent excision via the limbal conjunctival autograft technique. Normal conjunctival samples were collected from the superotemporal bulbar conjunctival region, just temporal to the site from which the autograft conjunc- 
tival tissue had been harvested. All patients underwent a complete ophthalmic examination. None of the patients had any type of ocular disease other than pterygium or any systemic inflammatory disorder. All surgeries were performed under local anesthesia using a surgical microscope. To ensure that the pathologist examining the samples was blinded to the samples, the excised pterygium tissue samples were labeled as $A$ and the conjunctival autograft tissue samples ( $2 \times 2 \mathrm{~mm}$ ) obtained from normal conjunctiva tissue were labeled as B. The examining pathologist was also blinded to the primary and recurrent pterygium tissue samples. The examining pathologist was unaware of the primary or recurrent status of the pterygial tissue samples which were labeled as A.

The study protocol was approved by the Erciyes University School of Medicine Ethics Committee, all procedures were performed in accordance with the tenets of the Declaration of Helsinki, and informed consent was obtained from all the patients.

\section{Pathological investigation}

After sectioning 50 randomly selected pterygium (primary and recurrent) and normal conjunctiva tissue (control) samples along the longitudinal axis, they were fixed in 10\% buffered formalin for $24 \mathrm{~h}$, and then processed for paraffin embedding. Next, the paraffin-embedded specimens were cut into $4-\mu \mathrm{m}$ sections and stained with $1 \%$ toluidine blue for $10 \mathrm{~min}$. Metachromatic cells were considered to be mast cells. The number of mast cells in 4 high-power fields $(400 \times)$ was calculated.

\section{Statistical analysis}

Statistical analysis was performed using SPSS v.16.0 for Windows. The Kolmogorov-Smirnov test and Shapiro-Wilk's test were used to determine whether or not the variables were normally distributed. Descriptive data were presented as mean \pm SD for normally distributed variables. Student's paired samples t-test was used to compare the mast cell count in normal tissue and pterygium tissue samples. The independent samples t-test was used to compare the mast cell count in primary and recurrent pterygium tissue specimens. The level of statistical significance was set at $P<0.05$.

\section{RESULTS}

The study included 26 female and 24 male patients with a mean age of $46.32 \pm 15.94$ years at the time of surgery. Mean age was similar in both groups: $47.82 \pm 15.82$ years for the PP group $(n=22)$ and 45.14 \pm 16.23 years for the VRP group $(n=28)(P>0.05)$. The mean mast cell count was $7.45 \pm 2.06 \mathrm{~mm}^{-2}$ in the PP group, versus $16.11 \pm 4.33 \mathrm{~mm}^{-2}$ in the VRP group, and the difference was significant (independent samples t-test, $P<0.001)$. Additionally, the mean mast cell count in pterygium samples was significantly higher than in the normal conjunctiva samples in both groups (Student's t-test, $P<0.001$ ). All of the findings are summarized in the table.

\section{DISCUSSION}

Mast cells actively play a role in innate and acquired immune reactions, as well as in a series of fundamental functions, including angio-

Table. Mean \pm SD mast cell counts, according to group and tissue

\begin{tabular}{lcccc} 
sample & & & & \\
\hline Group & Normal conjunctiva & Pterygium & $\mathbf{n}$ & $\mathbf{P}$ \\
\hline PP & $3.23 \pm 1.54$ & $7.45 \pm 2.06$ & 22 & $<0.001^{*}$ \\
VRP & $10.57 \pm 3.16$ & $16.11 \pm 4.33$ & 28 & $<0.001^{*}$ \\
PP vs. VRP & & & & $<0.005^{* *}$ \\
\hline
\end{tabular}

$\mathrm{PP}=$ primary pterygium; $\mathrm{VRP}=$ vascularized recurrent pterygium; ${ }^{*}=$ paired $\mathrm{t}$-test; ${ }^{* *}=$ in dependent t-test. genesis. Mast cells synthesize and release many angiogenic growth factors that are necessary for new vessel development ${ }^{(12)}$. Ribatti et al. reported that mast cells are involved in the angiogenesis of pterygium, which could be one of the reasons for their development ${ }^{(7)}$. Aspiotis et al. noted that the density of microvessels in pterygium was significantly higher than in normal conjunctiva, and that the overexpression of VEGF was among the most potent angiogenic factors ${ }^{(10)}$. The number of mast cells in pterygium is higher than that in normal conjunctiva ${ }^{(5,6)}$. It was also reported that angiogenesis - measured according to microvessel density - is strongly correlated with the tryptase-positive mast cell count in pterygium tissues ${ }^{(7)}$.

The literature includes few studies on the differences in the pathophysiology of primary and recurrent pterygia. The number of mast cells and microvessels increased in the formation of pterygium. It has been reported that VEGF and neo-vessels play an important role in the pathogenesis of pterygium ${ }^{(13,14)}$, as do mast cells ${ }^{(7,15)}$; however, to the best of our knowledge, the present study is the first to compare the mast cell count in primary pterygium and vascular recurrent pterygium. In the present study, the mast cell count was two-fold higher in vascularized recurrent pterygium and even in the normal conjunctival region of the recurrent vascularized pterygium tissues. Moreover, Liang et al. ${ }^{(16)}$ reported that there was a strong correlation between the mast cell and microvessel counts, indicating that mast cells promoted neovascularization in pterygia. They also reported that the number of mast cells was correlated with capillary density.

Regarding inflammation, the mast cell count differed significantly between pterygium tissue and normal conjunctiva as was also shown in the current study. Butrus et al. reported that the mast cell count was two-fold higher in pterygium tissue than in normal conjunctiva tissues in age-matched controls ${ }^{(15)}$. Nakagami et al. also reported a two-fold increase in the mast cell count in pterygium tissue, as compared to normal conjunctiva tissue. Toluidine blue staining has shown that the mean number of mast cells in pterygium tissue specimens was twice that in normal conjunctiva tissue specimens ${ }^{(8)}$. Zhong et al. compared the mast cell count in 17 primary pterygia, 6 recurrent pterygia, and 6 normal conjunctiva specimens, and reported that the mast cell count was $45.47 \mathrm{~mm}^{-2}$ in the primary pterygium samples and $48.83 \mathrm{~mm}^{-2}$ in the recurrent pterygium samples; both of these findings were significantly higher than in the normal conjunctiva samples ${ }^{(17)}$. Ermis et al. ${ }^{(18)}$ also observed that the mast cell count was higher in pterygium tissue. In all their patients with pterygium in one eye, the mast cell count was higher in pterygium tissue than in the normal conjunctiva of the unaffected eye.

In agreement with previously reported studies, the mast cell count was two-fold higher in primary pterygium tissue than in normal conjunctiva tissue in the present study; however, the mast cell count in the vascularized recurrent pterygium was not two-fold higher than in normal conjunctiva tissue. Nonetheless, the mast cell counts in the recurrent vascularized pterygium tissue and in normal conjunctival tissue were much higher than in the primary pterygium tissue. We think that perhaps a high mast cell count, which is an indicator of increased inflammation, in the overall bulbar conjunctiva tissue - including the normal section - could be the cause of recurrence in patients with vascularized pterygium. It is difficult to determine a definitive mast cell count cut-off value that would be predictive of recurrence of pterygium tissue based on the present findings, but $<10$ mast cells $\mathrm{mm}^{-2}$ in the excised pterygium tissue could be a predictor of recurrence.

Ratnakar et al. ${ }^{(19)}$ examined 30 pterygium specimens microscopically and classified the lesions as angiomatous, fibrous, and mixed, based on the vascular and collagenous components. They determined that the mast cell count in each type of lesion was strongly correlated with morphological type, as compared to normal conjunctiva. The mast cell count in angiomatous and fibrous types was $15.1 \pm 3.1 \mathrm{~mm}^{-2}$ and $9.5 \pm 3.2 \mathrm{~mm}^{-2}$, respectively. The researchers posited that an elevated mast cell count could be a predictor for the 
recurrence of pterygium. In the present study, there was a significant difference in the mast cell count between primary and recurrent vascularized pterygium tissue samples.

Mast cell mediators are involved in numerous aspects of inflammation, including remodeling, tissue repair, and fibrosis ${ }^{(20)}$. These functions are accomplished via mast cells' direct stimulation of specific connective tissue cell types - in particular, fibroblasts - and via the release or activation of a series of extracellular matrix-degrading enzymes ${ }^{(12)}$. It has been reported that there is an increase in the proliferation of the fibrovascular layer in recurrent pterygium ${ }^{(21)}$ and the association with an increase in the fibrovascular layer in recurrent pterygium could be due to an increase in the mast cell count. This was also shown in the present study.

A potential limitation of the present study was that vascularized recurrent pterygium tissues were used for enumerating the mast cell count. All the included patients that had vascularized recurrent pterygium had ocular discomfort and were eager to undergo a second surgery, whereas those that had recurrent pterygium with a prominent fibrous component were not eager to have a second surgery. Subsequently, these types of recurrent pterygium tissues were not encountered in this study. Most likely the ocular discomfort in the study patients was a result of an increase in inflammation and the number of mast cells in inflamed areas. Additional studies on recurrent pterygium tissue with a prominent fibrous component that investigated the difference in the mast cell count between the different types of pterygium tissue will be needed to more clearly determine the role of an elevated mast cell count in the pathogenesis of the recurrence of all types of pterygium.

\section{CONCLUSIONS}

The literature includes only a few studies on the differences between the pathophysiology of primary and recurrent pterygium. Mast cell involvement in the pathogenesis of pterygium has been reported. The present findings show that an increased in the number of mast cells can play a role in the pathogenesis of the recurrence in pterygium. A mast cell count cut-off value in the excised pterygium tissue could be used to screen patients at risk of recurrence. Additionally, new drugs that inhibit mast cell degranulation or currently-used mast cell stabilizers after pterygium excision might yield new methods for the prevention of recurrence of pterygium; this will require additional research.

\section{REFERENCES}

1. Kase S, Takahashi S, Sato I, Nakanishi K, Yoshida K, Ohno S. Expression of p27 (KIP1) and cyclin D1, and cell proliferation in human pterygium. Br J Ophthalmol. 2007; 91(7):958-61. Comment in: Br J Ophthalmol. 2008;92(1):157.

2. Galli SJ. New concepts about the mast cell. N Engl J Med. 1993;328(4):257-65.

3. Ribatti D, Crivellato E, Roccaro AM, Ria R, Vacca A. Mast cell contribution to angiogenesis related to tumour progression. Clin Exp Allergy. 2004;34(11):1660-4.

4. Szukiewicz D, Gujski M, Maslinska D, Szewczyk G, Bachanek M, Maslinski S. Mast cell-derived VEGF and VEGF receptor type 1,2, and 3 expression in human term trophoblast culture -influence of hypoxia. Inflamm Res. 2005;54 Suppl 1:S82-3.

5. Powers MR, Qu Z, O'Brien B, Wilson DJ, Thompson JE, Rosenbaum JT. Immunolocalization of bFGF in pterygia: association with mast cells. Cornea. 1997;16(5):545-9.

6. Nakagami T, Murakami A, Okisaka S, Ebihara N. [Pterygium and mast cells - mast cell number, phenotype, and localization of stem cell factor]. Nihon Ganka Gakkai Zasshi. 1997:101(8):662-8. Japanese.

7. Ribatti D, Nico B, Maxia C, Longo V, Murtas D, Perra MT, et al. Neovascularization and mast cells with tryptase activity increase simultaneously in human pterygium. J Cell Mol Med. 2007:11(3):585-9.

8. Nakagami T, Murakami A, Okisaka S, Ebihara N. Mast cells in pterygium: number and phenotype. Jpn J Ophthalmol. 1999;43(2):75-9.

9. Kria L, Ohira A, Amemiya T. Growth factors in cultured pterygium fibroblasts: immunohistochemical and ELISA analysis. Graefes Arch Clin Exp Ophthalmol. 1998;236(9): 702-8.

10. Aspiotis M, Tsanou E, Gorezis S, loachim E, Skyrlas A, Stefaniotou M, et al. Angiogenesis in pterygium: study of microvessel density, vascular endothelial growth factor, and thrombospondin-1. Eye (Lond). 2007;21 (8):1095-101.

11. Nolan TM, Di Girolamo N, Coroneo MT, Wakefield D. Proliferative effects of heparin-binding epidermal growth factor-like growth factor on pterygium epithelial cells and fibroblasts. Invest Ophthalmol Vis Sci. 2004;45(1):110-3.

12. Ribatti $D$, Crivellato E. Mast cells, angiogenesis, and tumour growth. Biochim Biophys Acta. 2012;1822(1):2-8.

13. Khalfaoui T, Mkannez G, Colin D, Imen A, Zbiba W, Errais K, et al. Immunohistochemical analysis of vascular endothelial growth factor (VEGF) and p53 expression in pterygium from Tunisian patients. Pathol Biol (Paris). 2011;59(3):137-41.

14. Lee DH, Cho HJ, Kim JT, Choi JS, Joo CK. Expression of vascular endothelial growth factor and inducible nitric oxide synthase in pterygia. Cornea. 2001;20(7):738-42.

15. Butrus SI, Ashraf MF, Laby DM, Rabinowitz Al, Tabbara SO, Hidayat AA. Increased numbers of mast cells in pterygia. Am J Ophthalmol. 1995;119(2):236-7.

16. Liang $K$, Jiang Z, Zhao B, Shen J, Huang D, Tao L. The expression of vascular endothelial growth factor in mast cells promotes the neovascularisation of human pterygia. $\mathrm{Br} J$ Ophthalmol. 2012;96(9):1246-51

17. Zhong $Y$, Ding $K$, Ye $W$. [The relation between expression of basic fibroblast growth factor and mast cells in pterygium]. Zhonghua Yan Ke Za Zhi. 2001;37(6):455-7. Chinese.

18. Ermis SS, Aktepe F, Inan UU, Ozturk F, Dilek H. Pterygium vs mast hucresi, T Klin J Oftalmoloji. 2003;12(2):92-5.

19. Ratnakar KS, Goswamy V, Agarwal LP. Mast cells and pterygium. Acta Ophthalmol (Copenh). 1976;54(3):363-8.

20. Artuc M, Steckelings UM, Henz BM. Mast cell-fibroblast interactions: human mast cells as source and inducers of fibroblast and epithelial growth factors. J Invest Dermatol. 2002;118(3):391-5.

21. Tan DT, Liu YP, Sun L. Flow cytometry measurements of DNA content in primary and recurrent pterygia. Invest Ophthalmol Vis Sci. 2000;41(7):1684-6. 